This is a post-print version of an article published in Marine Ecology Progress Series. The final published version is available online at: https://doi.org/10.3354/meps12544. Rossi S, Elias-Piera F (2018) Trophic ecology of three echinoderms in deep waters of the Weddell Sea (Antarctica). Mar Ecol Prog Ser 596:143-153.

\title{
Trophic ecology of three echinoderms in deep waters of the Weddell
} Sea (Antarctica)

${ }^{1}$ DiSTeBA, University of Salento, 73100 Lecce, Italy

${ }^{2}$ Institut de Ciència i Tecnologia Ambientals (UAB), Campus UAB s/n, Barcelona 08193, Spain

${ }^{3}$ Division of Polar Ocean Environment, Korea Polar Research Institute, Incheon 21990, South Korea

* Corresponding author: sergio.rossi@ unisalento.it

RUNNING TITLE: Rossi \& Elias-Piera: Trophic ecology of Antarctic deep-sea echinoderms ABSTRACT In the Southern Ocean, the trophic ecology of deep-sea communities is probably one of the most neglected fields in the discipline. In the present study, the trophic position and energy storage-mobilization of 3 different deep-sea echinoderms living in the Weddell Sea (around $1500 \mathrm{~m}$ depth) were investigated with indirect tools (i.e. stable isotopes, carbohydratelipid-protein balance, and free fatty acid [FFA] contents). The stalked crinoid Dumetocrinus antarcticus, the holothurian Rhipidothuria racovitzai, and the ophiuroid Ophiura carinifera were sampled in spring 2003 during a Polarstern cruise. We found that stable isotopes were in line with previous results of other species $\left(\delta^{13} \mathrm{C}\right.$ ranging from $-24.3 \%$ to $-26.5 \%$; $\delta^{15} \mathrm{~N}$ ranging from $6.8 \%$ o to $7.9 \%$ ), showing similarities in the trophic position of the 3 echinoderms. The capability to store energy by these 3 organisms is conspicuous and different, e.g. from 18 to $45 \%$ of the organic matter $(\mathrm{OM})$ consists of lipids. The capability to mobilize energy in the form of carbohydrates and FFAs among species was also very different (e.g. biomolecules ranging from 9 to $22 \mu \mathrm{g}$ carbohydrates $\mathrm{mgOM}^{-1}$ and from 4 to $39 \mu \mathrm{g} \mathrm{FFA} \mathrm{mgOM}^{-1}$ ). It is suggested that even if the trophic level is similar in the 3 echinoderms, the strategies to invest the energy inputs in these deep-sea organisms in polar environments may be quite different.

KEY WORDS: Suspension feeders - Deposit feeders · Fatty acids · Stable isotopes · Energy storage $\cdot$ Antarctica $\cdot$ Biomarkers $\cdot$ Deep sea

\section{INTRODUCTION}

An important part of the seasonal primary productivity in Antarctic waters (up to $90 \%$ at the beginning of the blooms in polar waters; Wassmann et al. 1991) arrives almost intact to the benthic communities, forming food banks (Gutt \& Starmans 1998, Mincks et al. 2005, Isla et al. 2006a,b). This organic matter fuels the overall system for weeks or months (Holm-Hansen 1985, Clarke 1988, Piepenburg et al. 1997). In the euphotic zone, twenty to forty intense blooms a year (produced between late spring and early autumn; Isla et al. 2009) produce a huge amount of particulate organic matter (POM) that is rapidly transferred to the benthic communities (Lampitt et al. 1993, Cattaneo-Vietti et al. 1999, Rossi et al. 2013, Gutt et al. 2017). This phenomenon 
produces a tight benthic-pelagic coupling in Antarctic waters (Ambrose \& Renaud 1997, Clough et al. 2005).

The highly diverse Antarctic bottoms (Arntz et al. 1994, Gili et al. 2001, Gili et al. 2006a, Gutt et al. 2017) hold a huge biomass in which suspension and deposit feeders have a prominent role. Among these organisms, echinoderms are very abundant and taxonomically diverse, capturing particles by actively intercepting the main currents, or by detecting and consuming the primary productivity and its associated microbial and metazoan community from the ocean floor (Gutt 1991, McClintock 1994, O’Loughlin et al. 2011, Ambroso et al. 2016). In general, information on the trophic ecology of benthic organisms in Antarctic waters is scarce (Orejas et al. 2001, Jacob et al. 2003; Gili et al. 2006b, Elias-Piera et al. 2013). Most trophic studies to date have been carried out in the Antarctic Peninsula and on the Weddell Sea continental shelf (150$2000 \mathrm{~m}$ depth) (McClintock 1994, Dahm 1999, Jacob et al. 2003, Purinton et al. 2008, Corsolini \& Borghesi 2017), thus trophic ecology information for the deep-sea areas of the Weddell Sea is still very scarce (Jacob et al. 2003).

These deep areas may also have an important presence of benthic suspension or deposit feeders (Brandt et al. 2007a,b; Gutt et al. 2017), but the trophic ecology of these organisms can only be guessed at, because very few studies have been made to date (see Frutos et al. 2017, Gutt et al. 2017). During the ANT XXI-2 'Polarstern' cruise (2003-2004), 3 different echinoderms were observed forming quite dense patches at $1500 \mathrm{~m}$ depth: the stalked crinoid Dumetocrinus antarcticus (Bather, 1908), the holothurian Rhipidothuria racovitzai (Hérouard, 1901), and the ophiuroid Ophiura (Ophiuroglypha) carinifera (Koehler, 1901). This suggests that primary productivity may also reach these deep zones in sufficient quantity to fuel these communities.

The stalked crinoid is a suspension feeder, fixed on the substrate (Macurda \& Meyer 1974). Its body shape and morphology indicates that this animal is adapted to intercept particles from the water column, as in other suspension-feeding species (Orejas et al. 2001). Like other suspension feeders, it therefore depends on the quantity and quality of the water column seston particles to feed (Gili \& Coma 1998). Other echinoderms may actively search for food in the food banks ('green carpets'; Mincks et al. 2005), which may be sparse in different areas. We do not have precise information about the trophic ecology of the holothurian, but it may be a deposit feeder, detecting and feeding on these degrading phytoplankton carpets present in the sediment (Gutt 1991, McClintock et al. 1994). Ophiuroids can be considered intermediate strategists between suspension feeding and deposit feeding (Gutt et al. 2017): they may be highly concentrated in soft bottoms where detritus is available, filtering the resuspended material (Piepenburg et al. 1997), and actively moving from patch to patch of detritus, taking advantage of the asymmetric distribution of organic matter (OM) in the soft bottom substrates (Piepenburg \& Juterzenka 1994).

In areas like the deep Antarctic benthos which are logistically difficult to access, direct tools (e.g. stomach contents, feeding experiments) are not a practical method to obtain a complete picture of the energy fluxes (Gili et al. 2006b). However, indirect methods, such as the integration of results for multiple biomarkers (e.g. stable isotopes, biochemical balance, and fatty acids) assessed in combination, have proven very useful in elucidating the trophic ecology of benthic organisms (e.g. Gori et al. 2012, Elias-Piera et al. 2013, Viladrich et al. 2017). The use of identifiable molecular biomarkers, which pass from food sources to the consumer, is also useful to detect soft-bodied microscopic prey, such as bacteria, phytoplankton, ciliates and flagellates (Rossi et al. 2006c). Using such indirect tools allows identification of food sources, trophic 
position of the organisms, the ecosystem's capability to store energy, or even the effects of environmental changes integrated over time (Viladrich et al. 2016a,b). For example, the proportions of carbon $\left(\delta^{13} \mathrm{C}\right)$ and nitrogen $\left(\delta^{15} \mathrm{~N}\right)$ stable isotopes may vary with nutrient source and trophic level of consumers. Stable isotope analysis has been successfully used to elucidate food source partitioning, and food web dynamics (Jacob et al. 2005, Mincks et al. 2008, Søreide et al. 2008, Elias-Piera et al. 2013). Also, overall fatty acid (FA) composition and specific FAs used as trophic markers can help to elucidate trophic relationships in food webs and quantify available mobilisable lipids (free fatty acids [FFAs]; Viladrich et al. 2016a,b). Finally, many organisms commonly use energy storage to cope with seasonal food shortages: protein, carbohydrate, and lipid levels may reflect food shortages in benthic aquatic organisms (Rossi et al. 2006a,b). Benthic-pelagic coupling processes may be thus studied using these indirect tools (Rossi et al. 2017).

Improving knowledge of the trophic ecology of deep-sea organisms, especially in Antarctic waters, will help in the understanding of biodiversity and ecosystem functioning in this remote area. In the present study, the 3 abovementioned echinoderm species were collected and analysed for stable isotopes, FFAs and biochemical balance (protein, lipid and carbohydrate content) to explore their trophic ecology in late spring Antarctic conditions. In this time of the year, food banks are almost depleted (Isla et al. 2011) and the cycle of primary productivity starts again. The study will be a key point to understand future changes in the trophic ecology of these considered important contributors of the biomass in Antarctica (Brey \& Gerdes 1998) in a fastchanging area.

\section{MATERIALS AND METHODS}

\section{Sampling area and sampled species}

The sampling area was located in the southwestern Weddell Sea, around $1500 \mathrm{~m}$ depth (Fig. 1; 707.88’'S; $11^{\circ} 21.56^{\prime} \mathrm{W}$ ).

The 3 echinoderm species sampled belong to 3 different classes: Rhipidothuria racovitzai is a holothurian, Dumetocrinus antarcticus is a crinoid, and Ophiura carinifera is an ophiuroid. In a bottom trawl made using an Agassiz Trawl, these were among the more abundant species found in the deep platform, and the only 3 echinoderm species found at that time in this sampling (Arntz \& Brey 2005). Also, the camera used in the Multi-Box Core (Arntz \& Brey 2005) recorded the presence of these 3 echinoderms as the more abundant species (D. Gerdes \& W. E. Arntz pers. comm.). Once collected, the animals (10-20 per species) were immediately frozen ($80^{\circ} \mathrm{C}$ ) and freeze-dried (at $-110^{\circ} \mathrm{C}$ and a pressure of $5 \mathrm{mbar}$ ), and then stored at $-20^{\circ} \mathrm{C}$ pending biochemical analysis.

\section{Stable isotope analysis}

Four replicates of freeze-dried holothurian tissue, ophiuroid and crinoid arms were weighed with a microbalance (Mettler Toledo, model XS3DU). Around 0.50 to $0.60 \mathrm{mg}$ of freeze dried samples were used for this analysis.

The samples were slightly acidified with $10 \% \mathrm{HCl}$ to remove carbonates, which can bias $\delta^{13} \mathrm{C}$ signatures (Jacob et al. 2005), following protocols from McConnaughey \& McRoy (1979), Hobson \& Welch (1992) and Jacob et al. (2005). 
The $\delta^{13} \mathrm{C}$ and $\delta^{15} \mathrm{~N}$ stable isotope analyses were performed with a mass spectrometer (Flash EA $1112 \mathrm{HT} \mathrm{O/H-N/C),} \mathrm{following} \mathrm{the} \mathrm{same} \mathrm{procedure} \mathrm{as} \mathrm{previously} \mathrm{described} \mathrm{in} \mathrm{Elias-}$ Piera et al. (2013). Isotopic ratios are expressed as parts per thousand (\%o) (difference from a standard reference material) according to the following equation:

$$
\delta X=\left[\left(R_{\text {sample }} / R_{\text {standard }}\right)-1\right] \times 10^{3}
$$

where $X$ is ${ }^{13} \mathrm{C}$ or ${ }^{15} \mathrm{~N}$ and $R$ is the corresponding ratio ${ }^{13} \mathrm{C} /{ }^{12} \mathrm{C}$ or ${ }^{15} \mathrm{~N} /{ }^{14} \mathrm{~N}$. $R_{\text {standard }}$ values for ${ }^{13} \mathrm{C}$ and ${ }^{15} \mathrm{~N}$ are from PeeDee Belemnite (PDB) and atmospheric $\mathrm{N}_{2}$, respectively.

\section{Organic matter content and biochemical balance}

The OM content and the lipid analysis were calculated by sub-sampling 35 to $50 \mathrm{mg}$ of holothurian tissue, ophiuroid and crinoid arms (10 per species). Samples were combusted at $500^{\circ} \mathrm{C}$ for $4 \mathrm{~h}$ in a muffle furnace (Relp $2 \mathrm{H}-\mathrm{M} 9$ ). The remaining inorganic ash was weighed. The difference between dry weight (DW) and ash weight gave the OM content (ash-free dry weight) (Slattery \& McClintock 1995, Rossi et al. 2006a,b).

The lipid analyses were performed spectrophotometrically and were quantified according to Barnes \& Blackstock (1973) in 10 samples per species. Around $11 \mathrm{mg}$ DW of holothurian tissue, around $35 \mathrm{mg} \mathrm{DW}$ of crinoid arms, and around $66 \mathrm{mg} \mathrm{DW}$ of ophiuroid arms were homogenised in $3 \mathrm{ml}$ of chloroform-methanol $(2: 1 \mathrm{v} / \mathrm{v})$, using cholesterol as a standard (absorbance vs. concentration). Results are presented in $\mu \mathrm{g}$ lipid (Lip) $\mathrm{mgOM}^{-1}$ (Rossi et al. 2006a, Elias-Piera et al. 2013).

Protein and carbohydrate analyses were performed applying spectrophotometric methodologies (10 samples per species and analytical procedure): 8 to $11.5 \mathrm{mg}$ tissue DW was weighed in a microbalance (precision: $\pm 0.01 \mathrm{mg}$ ) for each analysis (Rossi et al. 2006a, EliasPiera et al. 2013). The Lowry et al. (1951) method was followed for protein analysis. The tissue was homogenised in $1 \mathrm{ml}, 1 \mathrm{~N} \mathrm{NaOH}$, using albumin as a standard (absorbance vs. concentration). Carbohydrate content of tissues was analysed and quantified following Dubois et al. (1956). Each tissue was weighed and homogenised in $3 \mathrm{ml}$ of double distilled water, using glucose as a standard (absorbance vs concentration). Results are presented in $\mu \mathrm{g}$ protein (Prot) $\mathrm{mgOM}^{-1}$ and $\mu \mathrm{g}$ carbohydrate $(\mathrm{CHO}) \mathrm{mgOM}^{-1}$.

\section{Fatty acid analysis}

Holothurian tissue, ophiuroid and crinoid arms were analysed with gas chromatography to identify and quantify FFAs. Around 11 and $15 \mathrm{mg}$ DW of 4 replicates of holothurian arms, 4 of ophiuroid arms and 6 of crinoid arms were extracted with dichloromethane-methanol $(3: 1)$. An internal standard $(250 \mu 1$ of 2-octyldodecanoic acid, $5 \beta$-cholanic acid, 2-nonadecanone and hexatriacontane) was added. The extract was re-dissolved in $0.5 \mathrm{ml}$ of chloroform and passed through a $500 \mathrm{mg}$ aminopropyl mini-column (Waters Sep-Pak® Cartridges). The FFA fraction was dried with nitrogen flux and then methylated using a solution of methanol/ $\mathrm{BF}_{3}\left(20 \%\right.$ of $\mathrm{BF}_{3}$ diluted in methanol) heated at $90^{\circ} \mathrm{C}$ for $1 \mathrm{~h}$. Subsequently, $4 \mathrm{ml}$ of Milli-Q water saturated with $\mathrm{NaCl}$ was added and FAs were recovered as fatty acid methyl esters (FAMEs). FAMEs were analysed by gas chromatography (GC; Agilent 5890 Series II instrument equipped with a flame ionization detector and a splitless injector) and were identified by retention time in comparison with standard FAs (37 FAME compounds, Supleco® Mix $\mathrm{C}_{4}-\mathrm{C}_{24}$ ). FA quantification was 
performed through peak area integration in the GC traces (Chromquest 4.1 software). Results are presented in $\mu \mathrm{g}$ FFA $\mathrm{mgOM}^{-1}$.

The present protocol, with slight changes, has been previously used with different biological material (Rossi \& Fiorillo 2010, Gori et al. 2012, Rossi et al. 2013, Elias-Piera 2014, Viladrich et al. 2016a,b, 2017).

\section{Statistical analyses}

Analyses of potential differences in stable isotopic signature $\left(\delta^{13} \mathrm{C}\right.$ and $\left.\delta^{15} \mathrm{~N}\right)$ and lipidprotein-carbohydrate composition between species were performed with a 1-way ANOVA test (R-language function 'aov') and a post-hoc Tukey test (R-language function 'TukeyHSD') with a significance level of $p<0.05$. Data were previously analysed by the Shapiro-Wilk $(p=0.1)$ and Levene's Test $(\mathrm{p}=0.05)$ ( $\mathrm{R}$ language function 'Shapiro.test' and 'LeveneTest') to test normality and homogeneity of variances, respectively. Data met the criteria for parametric analysis after logarithmic transformation.

Analysis of similarity (ANOSIM;analogous to 1-way ANOVA) was conducted, and a principal components analysis (PCA) was performed to investigate which FAs were more representative in terms of abundance in the different echinoderms using the R-language function 'rda' (vegan library). The PCA was constructed using logarithmically transformed FA compositional data.

A multi-dimensional scaling (MDS) analysis using the PRIMER software was applied to investigate similarities (Bray-Curtis similarity) between the 3 species according the FAs. A SIMPER analysis using the FFAs was also conducted to evaluate the relative contribution of FAs to the dissimilarity of each species.

\section{RESULTS}

\section{Stable isotopes}

Fig. 2 shows the stable isotope proportion of the 3 species. The $\delta^{13} \mathrm{C}$ values of the 3 echinoderms ranged from -24.3 to $-26.5 \%$, but only the crinoid's value was significantly different from that of the other 2 species $\left(F_{9,2}=79.63, \mathrm{p}<000.1\right)$. The $\delta^{15} \mathrm{~N}$ values were similar among species, ranging from 6.8 to $7.9 \%$. The only difference was between the holothurian and the crinoid $\left(F_{9,2}=6.84, \mathrm{p}=0.0156\right)$.

\section{Carbohydrates, proteins and lipids}

Fig. 3 shows the biochemical balance (carbohydrate, protein and lipid content of the organic matter tissue). In Fig. 3A, carbohydrate concentration values of the 3 species are shown and ranged between 9 and $22 \mu \mathrm{gCHO} \mathrm{mgOM}^{-1}$. The carbohydrate, protein and lipid concentrations in the holothurian tissues were more than twice those of the other 2 studied species, being significantly different from them $\left(F_{27,2}=44.35, \mathrm{p}<0.001\right)$.

Fig. 3B shows the total protein content of the 3 species: this ranged from 159 to 211 $\mu \mathrm{gProt} \mathrm{mgOM}^{-1}$, but none of the differences were significant $\left(F_{27,2}=2.98, \mathrm{p}=0.0668\right)$.

Values of total lipids are shown in Fig. 3C and range between 179 and $448 \mu$ gLip $\mathrm{mgOM}^{-1}$. All the echinoderm species had high lipid concentrations, the highest value being 
found in the holothurian. Both the holothurian and the crinoid had significantly higher concentrations of total lipids than the ophiuroid $\left(F_{22,2}=21.14, \mathrm{p}<0.001\right)$.

\section{Fatty acid analyses}

The total concentration of FFAs was significantly higher in the holothurian than the other 2 studied species (Fig.4). In fact, the difference is around one order of magnitude higher in this organism than the sessile crinoid and the ophiuroid.

The proportions of the different groups of FFA in the 3 species are shown in Fig. 5. Except for the crinoid, polyunsaturated (PU)FAs were the most prominent FFAs found in this study, while saturated (S)FAs generally showed the lowest proportions of the totals. In the holothurian there was an increasing gradient from SAFA to mono-unsaturated (MU)FA to PUFA. The different FFAs were quite balanced in the sessile crinoid. In the ophiuroid, PUFAs were especially abundant.

In the 3 species, the 20:4(n-6) was the most prominent FFA (Fig. 6 ). Almost $30 \%$ of the FFA in the ophiuroid is 20:4(n-6), being more than $15 \%$ in the other 2 echinoderm species. The 16:1(n-9) was abundant in holothurian and crinoid, but almost not present in the ophiuroid. The proportions (in\%) of 22:6(n-3) had very asymmetric values among the 3 studied species, being very abundant in holothurian but only slightly above $0 \%$ and $5 \%$ in the other 2 species. The 22:1(n-9) - derived from the 18:1(n-9) - represents around 10\% in the sessile crinoid, but was almost non-existent in the other 2 species. The 24:1(n-9), derived from the 22:1(n-9), was only present in moderate amounts in the holothurian and the crinoid. Long-chain FFAs, e.g. 24:4(n-6) and 24:5(n-3), were especially notable in the ophiuroid.

The 3 species exhibited significant species-specific differences in FA composition (ANOSIM, $\mathrm{p}<0.01$ ). The PCA applied to the different FFAs clearly distinguishes the 3 different species (Fig.7); the same result appears on the MDS analysis taking into account $40 \%$ similarity (data not shown). The first 2 principal components (PC1 and PC2) accounted for $34.6 \%$ and $40.7 \%$ of the FA variation, respectively. For the crinoid and the ophiuroid, the FAs that mainly separate these species were the 20:2 (abundant in the ophiuroid at 11.5\%) and the 22:1 (abundant in the crinoid at 9.9\%). The holothurians were significantly different from the other 2 species, even though the most abundant FAs were the same in all 3 species: - 20:4(n-6) and 20:5(n-3).

From the SIMPER analysis, there was $80.18 \%$ dissimilarity between the holothurian and the crinoid and $89.95 \%$ dissimilarity between the holothurian and ophiuroid. The FA 22:6 contributed 10.61 and $10.14 \%$ to the dissimilarity, respectively. Other FAs making major contributions to the 2 dissimilarities were 20:4(n-6) (contributing 9.48 and $8.91 \%$, respectively), 16:0 (6.08 and 6.54\%), and 16:1 (6.05 and 6.32\%). The dissimilarity between crinoid and ophiuroid was $50.95 \%$, mainly due to the FAs 16:0 (9.29\% contribution), 20:4(n-6) (8.65\%), $16: 1(6.22 \%)$ and $22: 1(6.0 \%)$.

\section{DISCUSSION}

The present study shows that, although the trophic position of the 3 echinoderm species seems to be similar, there are significant differences among the holothurian (Rhipidothuria racovitzai), the crinoid (Dumetocrinus antarcticus), and the ophiuroid (Ophiura carinifera) storage and mobilization of lipids and carbohydrates in spring. 
Carbon stable isotopes corroborate the fact that the source of food are the recurrent phytoplankton blooms (Jacob et al. 2006, Mintenbeck et al. 2007, Mincks et al. 2008, Elias-Piera et al. 2013). Such primary productivity may arrive almost intact to the bottom (to the continental platform, 300-400 m depth; Rossi et al. 2013) and possibly in large quantities to the deep sea (Shimanaga \& Shiriyama 2000). The trophic position of the 3 organisms is quite similar to other suspension-feeding organisms (e.g. Antarctic gorgonians), having similar diets (Elias-Piera et al. 2013). The mixture of phytoplankton and reworked material (in which rotifers, copepods, ciliates and other fauna may be living) could be responsible for the elevated $\delta^{15} \mathrm{~N}$ values. These high values are also present in holothurians of shallow warm temperate seas (Grall et al. 2006, Carlier et al. 2007), and other deep-sea holothurians (Fanelli et al. 2011).

Of the FFAs found in the 3 species, the most dominant is the 20:4(n-6), with the 18:1(n9) and longer-chained $\left(\mathrm{C}_{24}\right)$ FAs also non-negligible. These fatty acids have been identified with an omnivorous diet (Graeve et al. 2001, Suhr et al. 2003, Würzberg et al. 2011), which is in line with the $\delta^{15} \mathrm{~N}$ values. The omnivore/carnivore diet is also evidenced by the 20:1 and 22:1 (Drazen et al. 2008). This seems to confirm that these organisms feed not only on the microalgae found in the food banks, but also on the associated biota - i.e.micro-organisms (Howell et al. 2003). The 20:4 and 20:5 FAs are abundant in various species of echinoderms (Ginger et al. 2000, Graeve et al. 2001, Howell et al. 2003, Drazen et al. 2008, Galloway et al. 2013, Corsolini $\&$ Borghesi 2017), being typical compounds of membrane lipids in marine organisms (Corsolini \& Borghesi 2017).

The amount of energy stored (in the form of lipids) is high or very high in the 3 species compared to other echinoderms in deep sea areas (Drazen et al. 2008). These values demonstrate a high capability to accumulate high quality energetic molecules that will be used to face starvation or/and reproductive periods in a highly seasonal environment. The capability to store energy will depend on the different life cycles and the different trophic guilds, which, in this case, can be considerably different between the 3 groups.

Reproduction features are, in fact, one of the key points in understanding energy storage in marine invertebrates (Rossi et al. 2017). The lower values of lipids found in O. carinifera (in the present study) compared with the holothurian may be partly explained by investment in the gonadal output of large eggs during this period. Interestingly, gamete production in this ophiuroid species takes a considerable amount of time, and is different depending on the year cycle considered (Grange et al. 2004). We suggest that brittle stars mainly invest energy stored after the window of primary production as reproductive output. The large amount of PUFA may also be an indicative marker, as these fatty acids are related to the development of membranes, nervous tissues and early stage development, transferred from mother to the offspring (Bell \& Sargent 1996, Viladrich et al. 2017). Sessile and low mobility animals living in deep waters may adjust their growth and reproduction according to temporally and spatially variable food availability (Yasuda et al. 2016). Organisms in the deep sea can thus exhibit temporal and spatial changes in the diet and in reproductive patterns depending on the presence of food banks (Galley 2003, Galley et al. 2008).

Mobility to search for food to achieve the energy storage needed for movement and reproduction is an important quality for at least the ophiuroid and the holothurian. The eurybathymetry of $O$. carinifera allows this species to inhabit both shallow areas and deep zones (Brey \& Gerdes 1998, Sands et al. 2013, Ambroso et al. 2016). The same species in different Weddell Sea areas may display very different lipid concentrations, depending on the 
environmental conditions (Elias-Piera et al. 2013). For example, the FA markers in King George Island and Larsen area A (Antarctic Peninsula) were very similar, and these 2 sites have a strong seasonal pattern of primary productivity blooms (Elias-Piera 2014, Sañé et al. 2011). However, in the Larsen areas B and C, the amounts of energy stored (and markers of diatom origin) were represented in higher amounts, demonstrating a link between food source and potential accumulation at higher trophic levels, as well as a differential capability to store energy within a single species (Elias-Piera 2014).

$R$. racovitzai has not only the highest amount of total lipids, but that its carbohydrate and FFAs stores are also significantly higher than in the other 2 echinoderms. Carbohydrates are labile molecules that can be readily incorporated into the Krebs cycle to satisfy metabolic energy demand. A high concentration of carbohydrates in suspension feeders is related to periods in which there is a high metabolic demand (Rossi et al. 2006b). This is interesting, since we find that the FFAs also have a higher concentration in this species than the other 2 echinoderms. Most lipid components that can be considered energy reserves may be oxidised to obtain FFAs (Gurr et al. 2002); those FFAs can be beta-oxidised providing highly efficient energy sources (i.e. a high ATP/FA relationship; Sargent et al. 1988). This means that, among the 3 studied echinoderms, the holothurian seems to be the more metabolically active during the spring period studied (both carbohydrates and FFAs are significantly higher). In this time of the year (and in this area), sediments are quite poor in labile organic material (Isla et al. 2011). We suggest that holothurians are capable of moving, locating, and grazing directly on fresh (and patchily distributed) new green carpets, produced during the first spring blooms, and on the chlorophyll $a$ (primary productivity) below the sediment surface. However, this movement has a metabolic cost in terms of respiration and energy mobilization. Thus, the difference in energy storage, but especially in mobilizable molecules, may be thus partly explained because of this behaviour. In deep waters, holothurians may digest up to $63 \%$ of the biopolymeric carbon found in the surrounding sediments (especially proteins, but also lipids and carbohydrates) (Amaro et al. 2010), so the transfer of organic matter is quite efficient. The deposit feeder can select, ingest and assimilate the available organic matter (Hudson et al. 2004) using foraging and digestion strategies, which can involve 2 cases: a particle selection where the animal chooses food-rich matter during the capture of particles and ingestion (Levin et al. 1997, Billett et al. 2001, Purinton et al. 2008) or a selective assimilation where the animal digests and/or assimilates a subset of organic matter in its gut (Penry \& Jumars 1990, Purinton et al. 2008). In Protelpidia murrayi, Bathyplotes bongraini and Molpadia musculus, the second case occurs, increasing the selective digestion and/or assimilation due to the selectivity of phytodetritus clumps during ingestion (Purinton et al. 2008).

D. antarcticus cannot choose the ingested material, being a sessile suspension feeder. This echinoderm is present in large numbers in the Antarctic Peninsula continental platform (Larsen) and deep areas (Gutt et al. 2011, Eléaume et al. 2012). This crinoid intercepts the particles by expanding its complex branches to the main flux (Macurda \& Meyer 1974). The reproduction of these organisms in deep waters is completely unknown: no cycle of gonadal development or gonadal output observation has been made so far. Based on other Antarctic suspension feeding organisms such as gorgonians (Orejas et al. 2007), this strategy may also accumulate large quantities of lipids (Elias-Piera et al. 2013) to produce gametes that will be released in summer-autumn. However, this hypothesis needs to be tested in further research, since we did not observe any sexual product in the $D$. antarcticus collected. The amount of labile macromolecules ready to be mobilised (carbohydrates and FFAs found in the tissues) was low, 
and it is possible that the stalked crinoids may simply use the reserves accumulated in summerautumn and maintained through the resuspension processes in winter, to survive until a new set of phytoplankton blooms bring food to their filter organs.

Interestingly, related to the fact that the samples were collected at the beginning of spring, the 3 echinoderms contained long-chain FFAs. These molecules are considered of high energetic content (Dalsgaard et al. 2003), and may be a key factor to face seasonal (winter) food constraints in benthic suspension feeders in Antarctica (Servetto et al. 2017). The observed lipids and proteins may indicate a clear tendency toward a mechanism of energy accumulation instead of growth (Elias-Piera et al. 2013), which has been demonstrated to be very slow in the few suspension-feeding organisms analysed in Antarctic waters (Martínez-Dios et al. 2016). Deep sea waters in Antarctica are one of the less studied environments worldwide. The strong seasonality also affects these remote areas, in which the abundance of different organisms is not negligible (Brandt et al. 2007a,b). This may be due to an accumulation of labile material that possibly remains intact for months, as mentioned in the 'Introduction'. In the Orleans Submarine Canyon (Brandsfield Strait, Antarctic Peninsula), a high amount of lipids was detected in the sediments, being almost 2 orders of magnitude higher relative to the shallower water sediments (S. Rossi unpubl. data). In fact, downslope flows occur in this area continuously (Baines \& Condie 1998), fueling the deeper areas with a high quality of organic matter in productive periods. Deep zones in these areas of the Southern Ocean may thus be richer than other areas of the world in which the primary productivity is high, but the low temperature in deep sea decreases the metabolism of the associated biota and helps to preserve the organic matter (Mincks et al. 2005, Isla et al. 2006b). The quantity of lipids accumulated in Antarctic organisms seems to be, in general, elevated compared to other areas of the world (Gili et al. 2006b, EliasPiera et al. 2013, Elias-Piera 2014, Servetto et al. 2017). In other cold seas, the response of the organisms to such phytoplankton blooms is similar, the accumulation of lipids being an important factor for their survivorship (Parrish et al. 2009). It is thus not surprising that the 3 studied echinoderms store a high amount of lipids, even at this time of the year, when the sources of food become scarcer (Isla et al. 2011). The high diversification of sea cucumbers in these deep-sea polar waters (O'Loughlin et al. 2011) may be partially explained by this high energetic content and a very stable environment that stimulates diversification and complex interactions between organisms (Gili et al. 2006b). A variable response to a phytoplankton bloom with respect to phenology, even within taxonomic orders, will depend on feeding behavior and gonadogenesis of the species (Parrish et al. 2009).

Climate change is expected to alter the relative contribution of food sources for benthic organisms (Rossi et al. 2017, Gaillard et al. 2017), so it will be essential to understand how expected alterations in available organic matter affect deep-sea communities and their adaptations. The use of indirect tools (biomarkers) may help obtain a clearer picture of what will happen in the coming decades to this rich, pristine but fragile area of the world.

Acknowledgements. We are grateful to Professor Wolf Arntz for suggestions in the early stages of this paper. Josep-Maria Gili, Enrique Isla, Dieter Gerdes, Pablo López-González and Covadonga Orejas helped in the collection and taxonomical recognition of the samples. Lucia Rizzo helped with her critical view in advanced versions of the manuscript. Thanks to C. Barboza for helping with statistical analyses. Financial support for this study was provided by the Spanish Antarctic Research Programme REN2000-3096-E/ANT. S.R. was funded with a Marie Curie International Outgoing Fellowship (ANIMAL FOREST HEALTH, Grant 
Agreement Number 327845) and P-SPHERE (COFUND Marie Curie, Grant Agreement Number 665919). F.E.P. received a grant from the National Research Council Brazil (CNPq, process 237677/2012-1) and is now funded by the Korea Polar Research Institute (PE17070). We are thankful for the support of the Generalitat de Catalunya to MERS (2014 SGR-1356), as well as the Alfred Wegener Institute for Polar and Marine Research (AWI), which kindly invited us to join both EASIZ expeditions. The assistance of many colleagues on board, and the crew of the RV 'Polarstern' is also gratefully acknowledged. This work is contributing to the ICTA María de Maetzu 'Unit of Excellence' (MinECo, MDM2015-0552).

\section{LITERATURE CITED}

<jrn>Amaro T, Bianchelli S, Billett DSM, Cunha MR, Pusceddu A, Danovaro R (2010) The trophic biology of the holothurian Molpadia musculus: implications for organic matter cycling and ecosystem functioning in a deep submarine canyon. Biogeosciences 7:2419-2432 doi:10.5194/bg-7-2419-2010</jrn>

$<$ jrn>Ambrose WG Jr, Renaud PE (1997) Does a pulsed food supply to the benthos affect polychaete recruitment patterns in the Northeast Water Polynya? J Mar Syst 10:483-495 doi:10.1016/S0924-7963(96)00053-X</jrn>

<jrn>Ambroso S, Böhmer A, López-González P, Teixidó N (2016) Ophiuroid biodiversity patterns along the Antarctic Peninsula. Polar Biol 39:881-895 doi:10.1007/s00300-016-1911$4</$ jrn $>$

<jrn>Arntz WE, Brey T (2005) The expedition Antarktis XXI/2 of RV Polarstern in 2003-2004. Ber Polar Meeresforsch 503:1-149</jrn>

<jrn>Arntz WE, Brey T, Gallardo V (1994) Antarctic zoobenthos. Oceanogr Mar Biol Annu Rev $32: 241-304</ \mathrm{jrn}>$

<unknown>Baines PG, Condie S (1998) Observations and modelling of Antarctic downslope flows: A review. In: Ocean, ice, and atmosphere: interactions at the Antarctic continental margin, Vol 75. American Geophysical Union, Washington, DC, p 29-49 </unknown>

<jrn>Barnes H, Blackstock J (1973) Estimation of lipids in marine animal tissues: detailed investigation of the sulphophosphovanillin method for 'total' lipids. J Exp Mar Biol Ecol 12:103-118 doi:10.1016/0022-0981(73)90040-3</jrn>

$<$ jrn>Bell MV, Sargent JR (1996) Lipid nutrition and fish recruitment. Mar Ecol Prog Ser 134:315-316 doi: $10.3354 /$ meps $134315</$ jrn>

<jrn>Billett DSM, Bett BJ, Rice AL, Thurston MH, Galéron J, Sibuet M, Wolff GA (2001) Long-term change in the mega- benthos of the Porcupine Abyssal Plain (NE Atlantic). Prog Oceanogr 50:325-348 doi:10.1016/S0079-6611(01)00060-X</jrn>

$<$ jrn> Brandt A, De Broyer C, De Mesel I, Ellingsen KE and others (2007a) The biodiversity of the deep Southern Ocean benthos. Philos Trans R Soc Lond B Biol Sci 362:39-66 PubMed doi:10.1098/rstb.2006.1952</jrn>

$<$ jrn>Brandt A, Gooday AJ, Brandao SN, Brix S and others (2007b) First insights into the biodiversity and biogeography of the Southern Ocean deep sea. Nature 447:307-311 PubMed doi:10.1038/nature05827</jrn> 
Brey T, Gerdes D (1998) High Antarctic macrobenthic community production. J Exp Mar Biol Ecol 231:191-200 https://doi.org/10.1016/S0022-0981(98)00060-4

<jrn>Carlier A, Riera P, Amouroux J, Bodiou JY, Grémare A, Gre A (2007) Benthic trophic network in the Bay of Banyuls-sur-Mer (northwest Mediterranean, France): An assessment based on stable carbon and nitrogen isotopes analysis. Estuar Coast Shelf Sci 72:1-15 doi:10.1016/j.ecss.2006.10.001</jrn>

<jrn>Cattaneo-Vietti R, Chiantore M, Misic C, Povero P, Fabiano M (1999) The role of pelagicbenthic coupling in structuring littoral benthic communities at Terra Nova Bay (Ross Sea) and in the Straits of Magellan. Sci Mar 63:113-121 doi:10.3989/scimar.1999.63s1113</jrn>

$<j r n>$ Clarke A (1988) Seasonality in the Antarctic marine environment. Comp Biochem Physiol B Comp Biochem 90:461-473 doi:10.1016/0305-0491(88)90285-4</jrn>

$<$ jrn>Clough LM, Renaud PE, Ambrose WG Jr (2005) Impacts of water depth, sediment pigment concentration, and benthic macrofaunal biomass on sediment oxygen demand in the western Arctic Ocean. Can J Fish Aquat Sci 62:1756-1765 doi:10.1139/f05-102</jrn>

$<$ jrn>Corsolini S, Borghesi N (2017) A comparative assessment of fatty acids in Antarctic organisms from the Ross Sea: Occurrence and distribution. Chemosphere 174:747-753 PubMed doi:10.1016/j.chemosphere.2017.02.031</jrn>

<jrn>Dalsgaard J, St John M, Kattner G, Müller-Navarra D, Hagen W (2003) Fatty acid trophic markers in the pelagic marine environment. Adv Mar Biol 46:225-340 PubMed doi:10.1016/S0065-2881(03)46005-7</jrn>

Dahm C (1999) Ophiuroids (Echinodermata) of southern Chile and the Antarctic: Taxonomy, biomass, diet and growth of dominant species. Sci Mar 63(Supp 1): 427-432 https://doi.org/10.3989/scimar.1999.63s1427

$<$ jrn>Drazen JC, Phleger CF, Guest MA, Nichols PD (2008) Lipid, sterols and fatty acid composition of abyssal holothurians and ophiuroids from the North-East Pacific Ocean: food web implications. Comp Biochem Physiol B: Biochem Mol Biol 151:79-87 PubMed doi:10.1016/j.cbpb.2008.05.013</jrn>

$<$ jrn>Dubois M, Gilles KA, Hamilton JK, Rebers PA, Smith F (1956) Colorimetric method for the determination of sugars and related substances. Anal Chem 28:350-356 doi:10.1021/ac60111a017</jrn>

<jrn>Eléaume M, Bohn JM, Roux M, Améziane N (2012) Stalked crinoids (Echinodermata) collected by the R/V Polarstern and Meteor in the south Atlantic and in Antarctica. Zootaxa $3425: 1-22</ \mathrm{jrn}>$

$<$ ths >Elias-Piera FE (2014) Biomarkers of bentho-pelagic coupling in Antarctica: a spatiotemporal comparison in the Weddell sea. Doctoral dissertation, Universitat Autònoma de Barcelonap <

<jrn>Elias-Piera FE, Rossi S, Gili JM, Orejas C (2013) Trophic ecology of seven Antarctic gorgonian species. Mar Ecol Prog Ser 477:93-106 doi:10.3354/meps10152</jrn>

$<$ jrn>Fanelli E, Cartes JE, Papiol V (2011) Food web structure of deep-sea macrozooplankton and micronekton off the Catalan slope: insight from stable isotopes. J Mar Syst 87:79-89 doi:10.1016/j.jmarsys.2011.03.003</jrn> 
Frutos I, Brandt A, Sorbe JC (2017)Deep-sea suprabenthic communities: the forgotten biodiversity. In: Rossi S, Bramanti L, Gori A, Orejas C (eds) Marine animal forests: the ecology of benthic biodiversity hotspots. Springer, Cham, p 446-475

$<$ jrn>Gaillard B, Meziane T, Tremblay R, Archambault P and others (2017) Food resources of the bivalve Astarte elliptica in a sub-Arctic fjord: a multi-biomarker approach. Mar Ecol Prog Ser 567:139-156 doi:10.3354/meps12036</jrn>

<ths>Galley E (2003) Reproductive responses of Antarctic benthos to the seasonal flux of surface-derived phytodetritus. PhD dissertation, University of Southampton

$<$ jrn>Galley EA, Tyler PA, Smith CR, Clarke A (2008) Reproductive biology of two species of holothurian from the deep-sea order Elasipoda, on the Antarctic continental shelf. Deep Sea Res II 55:2515-2526 doi:10.1016/j.dsr2.2008.07.002</jrn>

$<$ jrn>Galloway AWE, Lowe AT, Sosik EA, Yeung JS, Duggins DO (2013) Fatty acid and stable isotope biomarkers suggest microbe-induced differences in benthic food webs between depths. Limnol Oceanogr 58:1451-1462 doi:10.4319/lo.2013.58.4.1451</jrn>

Gili JM, Coma R (1998) Benthic suspension feeders: their paramount role in littoral marine food webs. Trends Ecol Evol 13:316-321 https://doi.org/10.1016/S0169-5347(98)01365-2

<jrn>Gili JM, Coma R, Orejas C, López-González PJ, Zabala M (2001) Are Antarctic suspension-feeding communities different from those elsewhere in the world? Polar Biol 24:473-485 doi: $10.1007 / \mathrm{s} 003000100257</ \mathrm{jrn}>$

$<$ jrn> Gili J, Arntz W, Palanques A, Orejas C and others (2006a) A unique assemblage of epibenthic sessile suspension feeders with archaic features in the high-Antarctic. Deep Sea Res II 53:1029-1105 doi:10.1016/j.dsr2.2005.10.021</jrn>

<jrn>Gili JM, Rossi S, Pagès F, Orejas C, Teixidó N, López-González PJ, Arntz WE (2006b) A new trophic link between the pelagic and benthic systems on the Antarctic shelf. Mar Ecol Prog Ser 322:43-49 doi:10.3354/meps322043</jrn>

$<$ jrn> Ginger M, Santos V, Wolff G (2000) A preliminary investigation of the lipids of abyssal holothurians from the north-east Atlantic Ocean. J Mar Biol Assoc UK 80:139-146 doi:10.1017/S0025315499001654</jrn>

<jrn>Gori A, Viladrich N, Gili JM, Kotta M, Cucio C, Magni L, Rossi S (2012) Reproductive cycle and trophic ecology in deep versus shallow populations of the Mediterranean gorgonian Eunicella singularis. Coral Reefs 31:823-837 doi:10.1007/s00338-012-0904-1</jrn>

$<$ jrn>Graeve M, Dauby P, Scailteur Y (2001) Combined lipid, fatty acid and digestive tract content analyses: a penetrating approach to estimate feeding modes of Antarctic amphipods. Polar Biol 24:853-862 doi:10.1007/s003000100295</jrn>

$<$ jrn>Grall J, Le Loch F, Guyonnet B, Riera P (2006) Community structure and food web based on stable isotopes ( $\square 15 \mathrm{~N}$ and $\square 13 \mathrm{C}$ ) analysis of a North Eastern Atlantic maerl bed. J Exp Mar Biol Ecol 338:1-15 doi:10.1016/j.jembe.2006.06.013</jrn>

$<$ jrn>Grange LJ, Tyler PA, Peck LS, Cornelius N (2004) Long-term interannual cycles of the gametogenic ecology of the Antarctic brittle star Ophionotus victoriae. Mar Ecol Prog Ser 278:141-155 doi:10.3354/meps278141</jrn> 
<bok>Gurr MI, Harwood JL, Frayn KN (2002) Lipid biochemistry: an introduction. SpringerVerlag, Berlin</bok>

$<$ jrn > Gutt J (1991) On the distribution and ecology of holothurians in the Weddell Sea (Antarctica). Polar Biol 11:145-155 doi:10.1007/BF00240203</jrn>

$<$ jrn>Gutt J, Starmans A (1998) Structure and biodiversity of megabenthos in the Weddell and Lazarev Seas (Antarctica): ecological role of physical parameters and biological interactions. Polar Biol 20:229-247 doi:10.1007/s003000050300</jrn>

$<$ jrn $>$ Gutt J, Barratt I, Domack E, d'Udekem d'Acoz C and others (2011) Biodiversity change after climate-induced ice-shelf collapse in the Antarctic. Deep Sea Res II 58:74-83 doi:10.1016/j.dsr2.2010.05.024</jrn>

<edb>Gutt J, Cummings V, Dayton PK, Isla E, Jentsch A, Schiaparelli S (2017) Antarctic Marine animal forests: three-dimensional communities in Southern Ocean ecosystems. In: Rossi S, Bramanti L, Gori A, Orejas C (eds) Marine animal forests: the ecology of benthic biodiversity hotspots. Springer, Cham, p 315-344</edb>

$<$ jrn>Hobson KA, Welch HE (1992) Determination of trophic relationships within a high Arctic marine food web using $\square 13 \mathrm{C}$ and $\square 15 \mathrm{~N}$ analysis. Mar Ecol Prog Ser 84:9-18 doi: 10.3354/meps084009</jrn>

<edb>Holm-Hansen O (1985) Nutrient cycles in Antarctic marine ecosystems. In: Siegfried WR, Condy PR, Laws RM (eds) Antarctic nutrient cycles and food webs. Springer, Berlin, p 6$10</ \mathrm{edb}>$

$<$ jrn> Howell KL, Pond DW, Billett DSM, Tyler PA (2003) Feeding ecology of deep-sea seastars (Echinodermata : Asteroidea): a fatty-acid biomarker approach. Mar Ecol Prog Ser 255:193206 doi:10.3354/meps255193</jrn>

<>Hudson IR, Pond DW, Billett DSM, Tyler PA, Lampitt RS, Wolff GA (2004) Temporal variations in fatty acid composition of deep-sea holothurians: evidence of bentho-pelagic coupling. Mar Ecol Prog Ser 281:109-120<> https://doi.org/10.3354/meps281109

<jrn>Isla E, Gerdes D, Palanques A, Gili JM, Arntz WE (2006a) Particle flux near the continental ice edge on the eastern Weddell Sea shelf. Deep Sea Res II 53:866-874 doi:10.1016/j.dsr2.2006.02.010</jrn>

<jrn>Isla E, Rossi S, Palanques A, Gili JM, Gerdes D, Arntz WE (2006b) Biochemical composition of marine sediment from the eastern Weddell Sea (Antarctica): High nutritive value in a high benthic-biomass environment. J Mar Syst 60:255-267 doi:10.1016/j.jmarsys.2006.01.006</jrn>

<jrn>Isla E, Gerdes D, Palanques A, Gili JM, Arntz WE, König-Langlo G (2009) Downward particle fluxes, wind and a phytoplankton bloom over a polar continental shelf: A stormy impulse for the biological pump. Mar Geol 259:59-72 doi:10.1016/j.margeo.2008.12.011</jrn>

<jrn>Isla E, Gerdes D, Rossi S, Fiorillo I, Sañe E, Gili JM, Arntz W (2011) Biochemical characteristics of surface sediments on the eastern Weddell Sea continental shelf, Antarctica: is there any evidence of seasonal patterns? Polar Biol 34:1125-1133 doi:10.1007/s00300-0110973-6</jrn> 
Jacob U, Terpstra S, Brey T (2003) High-Antarctic regular sea urchins - the role of depth and feeding in niche separation. Polar Biol 26:99-104 https://doi.org/10.1007/s00300-002-0453-0

<jrn>Jacob U, Mintenbeck K, Brey T, Knust R, Beyer K (2005) Stable isotope food web studies: a case for standardized sample treatment. Mar Ecol Prog Ser 287:251-253 doi: $10.3354 /$ meps $287251</$ jrn $>$

$<$ jrn> Jacob U, Brey T, Fetzer I, Kaehler S and others (2006) Towards the trophic structure of the Bouvet Island marine ecosystem. Polar Biol 29:106-113 doi:10.1007/s00300-005-0071$8</$ jrn $>$

<jrn>Lampitt RS, Wishner KF, Turley CM, Angel MV (1993) Marine snow studies in the Northeast Atlantic Ocean: distribution, composition and role as a food source for migrating plankton. Mar Biol 116:689-702 doi:10.1007/BF00355486</jrn>

<jrn>Levin L, Blair N, DeMaster D, Plaia G, Fornes W, Martins C, Thomas C (1997) Rapid subduction of organic matter by maldanid polychaetes on the North Carolina Slope. J Mar Res 55:595-611 doi:10.1357/0022240973224337</jrn>

$<$ jrn>Lowry OH, Rosebrough NJ, Farr AL, Randall RJ (1951) Protein measurement with the Folin phenol reagent. J Biol Chem 193:265-275 PubMed</jrn>

$<$ jrn>Macurda DB, Meyer DL (1974) Feeding posture of modern stalked crinoids. Nature 247:394-396 doi:10.1038/247394a0</jrn>

<jrn>Martínez-Dios A, Dominguez-Carrió C, Zapata-Guardiola R, Gili JM (2016) New insights on Antarctic gorgonians' age, growth and their potential as paleorecords. Deep Sea Res I 112:57-67 doi:10.1016/j.dsr.2016.03.007</jrn>

$<$ jrn>McClintock J (1994) Trophic biology of antarctic shallow-water echinoderms. Mar Ecol Prog Ser 111:191-202 doi:10.3354/meps111191</jrn>

$<$ jrn>McConnaughey T, McRoy CP (1979) Food-web structure and the fractionation of carbon isotopes in the Bering Sea. Mar Biol 53:257-262 doi:10.1007/BF00952434</jrn>

$<$ jrn>Mincks SL, Smith CR, DeMaster DJ (2005) Persistence of labile organic matter and microbial biomass in Antarctic shelf sediments: evidence of a sediment 'food bank'. Mar Ecol Prog Ser 300:3-19 doi:10.3354/meps300003</jrn>

$<$ jrn>Mincks SL, Smith CR, Jeffreys RM, Sumida PY (2008) Trophic structure on the West Antarctic Peninsula shelf: detritivory and benthic inertia revealed by $\square 13 \mathrm{C}$ and $\square 15 \mathrm{~N}$ analysis. Deep Sea Res II 55:2502-2514 doi:10.1016/j.dsr2.2008.06.009</jrn>

<jrn>Mintenbeck K, Jacob U, Knust R, Arntz WE, Brey T (2007) Depth-dependence in stable isotope ratio $\square 15 \mathrm{~N}$ of benthic POM consumers: The role of particle dynamics and organism trophic guild. Deep Sea Res I 54:1015-1023 doi:10.1016/j.dsr.2007.03.005</jrn>

$<$ jrn>O'Loughlin PM, Paulay G, Davey N, Michonneau F (2011) The Antarctic region as a marine biodiversity hotspot for echinoderms: diversity and diversification of sea cucumbers. Deep Sea Res II 58:264-275 doi:10.1016/j.dsr2.2010.10.011</jrn>

<jrn>Orejas C, Gili JM, López-Gonzalez PJ, Arntz WE (2001) Feeding strategies and diet composition of four Antarctic cnidarian species. Polar Biol 24:620-627 doi:10.1007/s003000100272</jrn> 
<jrn>Orejas C, Gili JM, López-González PJ, Hasemann C, Arntz WE (2007) Reproduction patterns of four Antarctic octocorals in the Weddell Sea: an inter-specific, shape, and latitudinal comparison. Mar Biol 150:551-563 doi:10.1007/s00227-006-0370-9</jrn>

$<$ jrn>Parrish CC, Deibel D, Thompson RJ (2009) Effect of sinking spring phytoplankton blooms on lipid content and com- position in suprabenthic and benthic invertebrates in a cold ocean coastal environment. Mar Ecol Prog Ser 391:33-51 doi:10.3354/meps08148</jrn>

<jrn>Penry DL, Jumars PA (1990) Gut architecture, digestive con- straints and feeding ecology of deposit-feeding and carnivorous polychaetes. Oecologia 82:1-11 PubMed doi:10.1007/BF00318526</jrn>

Piepenburg D, von Juterzenka K (1994) Abundance, biomass and spatial distribution patterns of brittle stars (Echinodermata: Ophiuroldea) on the Kolbelnsey Ridge north of Iceland. Polar Biol 14:185-194 https://doi.org/10.1007/BF00240523

<jrn>Piepenburg D, Ambrose W, Brandt A, Renaud P, Ahrens M, Jensen P (1997) Benthic community patterns reflect water column processes in the Northeast Water Polynya (Greenland). J Mar Syst 10:467-482 doi:10.1016/S0924-7963(96)00050-4</jrn>

$<$ jrn>Purinton BL, DeMaster DJ, Thomas CJ, Smith CR (2008) 14C as a tracer of labile organic matter in Antarctic benthic food webs. Deep Sea Res II 55:2438-2450 doi:10.1016/j.dsr2.2008.06.004</jrn>

$<$ jrn>Rossi S, Fiorillo I (2010) Biochemical features of a Protoceratium reticulatum red tide in Chipana Bay (Northern Chile) in summer conditions. Sci Mar 74:633-642 doi:10.3989/scimar.2010.74n4633</jrn>

<jrn>Rossi S, Gili JM, Coma R, Linares C, Gori A, Vert N (2006a) Temporal variation in protein, carbohydrate, and lipid concentrations in (Anthozoa, Octocorallia): evidence for summer-autumn feeding constraints. Mar Biol 149:643-651 doi:10.1007/s00227-005-0229$5</ j r n>$

$<$ jrn>Rossi S, Snyder MJ, Gili JM (2006b) Protein-carbohydrate-lipid levels and HSP70- HSP90 (stress protein) expression over ran annual cycle of a benthic suspension feeder: useful tools to detect feeding constraints in a benthic suspension feeder. Helgol Mar Res 60:7-17 doi:10.1007/s10152-005-0009-0</jrn>

Rossi S, Sabat1007/s10152-005-0009-0vels anc) Lipid biomarkers and trophic linkages between phytoplankton, zooplankton and anchovy (Engraulis encrasicolus) larvae in the NW Mediterranean. J Plankton Res 28:551-562 https://doi.org/10.1093/plankt/fbi140

<jrn>Rossi S, Isla E, Martínez-García A, Moraleda N and others (2013) Transfer of seston lipids during a flagellate bloom from the surface to the benthic community in the Weddell Sea. Sci Mar 77:397-407 doi:10.3989/scimar.03835.30A</jrn>

<edb>Rossi S, Coppari M, Viladrich N (2017) Benthic-pelagic coupling: new perspectives in the animal forests. In: Rossi S, Bramanti L, Gori A, Orejas C (eds) Marine animal forests: the ecology of benthic biodiversity hotspots. Springer, Cham, p 855-886</edb>

<jrn>Sands CJ, Griffiths HJ, Downey RV, Barnes DKA, Linse K, Martín-Ledo R (2013) Observations of the ophiuroids from the West Antarctic sector of the Southern Ocean. Antarct Sci 25:3-10 doi:10.1017/S0954102012000612</jrn> 
Sañé E, Isla E, Grémare A, Gutt J, Vétion G, DeMaster DJ (2011) Pigments in sediments beneath recently collapsed ice shelves: The case of Larsen A and B shelves, Antarctic Peninsula. J Sea Res 65:94-102 https://doi.org/10.1016/j.seares.2010.07.005

<edb>Sargent JR, Parks RJ, Mueller-Harvey I, Henderson RJ (1988) Lipid biomarkers in marine ecology. In: Sliegh MA (ed) Microbes in the sea. Ellis Horwood, Chichester, p 119-38</edb>

<jrn>Servetto N, Rossi S, Fuentes V, Alurralde G, Lagger C, Sahade R (2017) Seasonal trophic ecology of the dominant Antarctic coral Malacobelemnon daytoni (Octocorallia, Pennatulacea, Kophobelemnidae). Mar Environ Res 130:264-274 PubMed doi:10.1016/j.marenvres.2017.08.003</jrn>

Shimanaga M, Shiriyama Y (2000) Response of benthic organisms to seasonal change of organic matter deposition in the bathyal Sagami Bay, Central Japan. Ocean Acta 23:91-107 https://doi.org/10.1016/S0399-1784(00)00103-1

$<$ jrn>Slattery M, McClintock JB (1995) Population structure and feeding deterrence in three shallow-water antarctic soft corals. Mar Biol 122:461-470 doi:10.1007/BF00350880</jrn>

$<$ jrn>Søreide JE, Falk-Petersen S, Hegseth EN, Hop H, Carroll ML, Hobson KA, BlachowiakSamolyk K (2008) Seasonal feeding strategies of Calanus in the high-Arctic Svalbard region. Deep Sea Res II 55:2225-2244</jrn> https://doi.org/10.1016/j.dsr2.2008.05.024

$<$ jrn>Suhr S, Pond D, Gooday A, Smith C (2003) Selective feeding by benthic foraminifera on phytodetritus on the western Antarctic Peninsula shelf: evidence from fatty acid biomarker analysis. Mar Ecol Prog Ser 262:153-162 doi:10.3354/meps262153</jrn>

<jrn>Viladrich N, Bramanti L, Tsounis G, Chocarro B and others (2016a) Variation in lipid and free fatty acid content during spawning in two temperate octocorals with different reproductive strategies: surface versus internal brooder. Coral Reefs 35:1033-1045 doi:10.1007/s00338-016-1440-1</jrn>

<jrn>Viladrich N, Rossi S, López-Sanz A, Orejas C (2016b) Nutritional condition of two coastal rocky fishes and the potential role of a marine protected area. Mar Ecol 37:46-63 doi:10.1111/maec. $12247</$ jrn>

<jrn>Viladrich N, Bramanti L, Tsounis G, Martínez-Quintana A, Ferrier-Pagés C, Rossi S (2017) Variation of lipid and free fatty acid contents during larval release in two temperate octocorals according to their trophic strategy. Mar Ecol Prog Ser 573:117-128 doi:10.3354/meps $12141</$ jrn>

$<$ jrn>Wassmann P, Peinert R, Smetacek V (1991) Patterns of production and sedimentation in the boreal and polar Northeast Atlantic. Polar Res 10:209-228 doi:10.3402/polar.v10i1.6740</jrn>

<jrn>Würzberg L, Peters J, Schüller M, Brandt A (2011) Diet insights of deep-sea polychaetes derived from fatty acid analyses. Deep Sea Res II 58:153-162 doi:10.1016/j.dsr2.2010.10.014</jrn>

<jrn> Yasuda N, Miyamoto N, Fuyiwara Y, Yamamoto T, Yusa Y (2016) Effects of food availability on growth and reproduction of the deep-sea pedunculate barnacle Heteralepas canci. Deep Sea Res I 108:53-57 doi:10.1016/j.dsr.2015.12.008</jrn> 
669

\section{7}

669

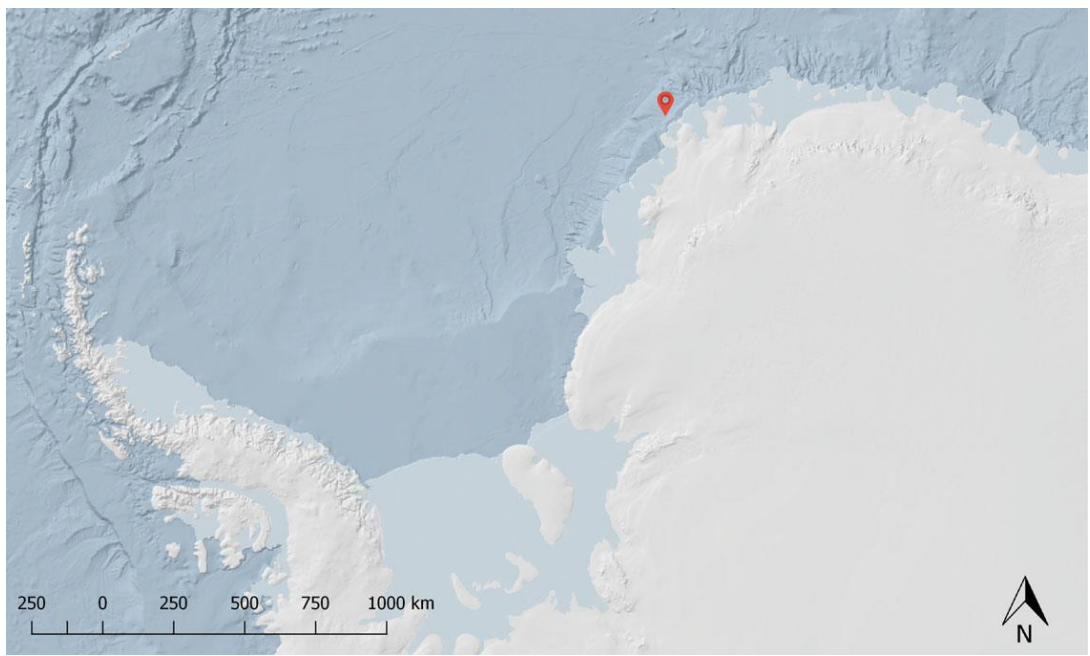

Fig. 1. Sampling area (red pin at $70^{\circ} 7.88^{\prime} \mathrm{S}, 11^{\circ} 21.56^{\prime} \mathrm{W}$ ) around $1500 \mathrm{~m}$ depth in the Weddell Sea (ANT XXI-2 Polarstern cruise)

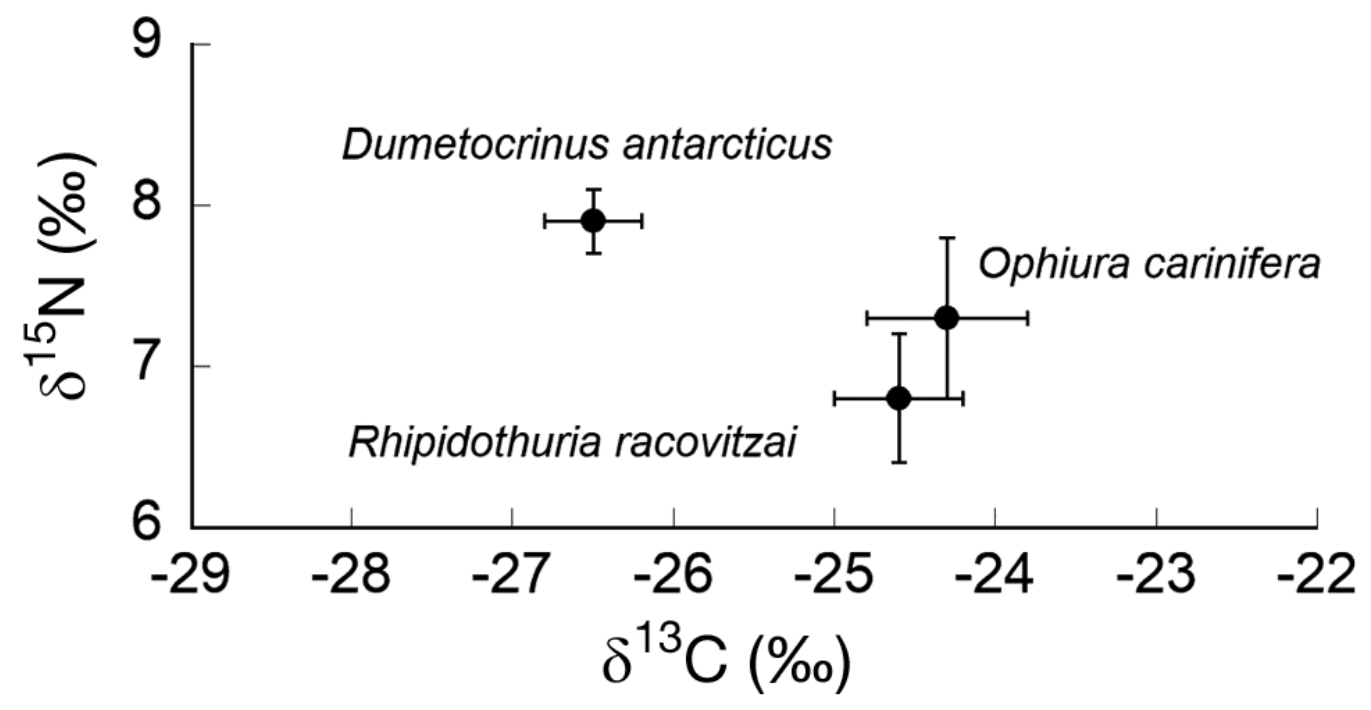

Fig. 2. Stable isotope values $\left(\delta^{13} \mathrm{C}\right.$ versus $\delta^{15} \mathrm{~N}$, in \%o) of the 3 species of echinoderms Rhipidothuria racovitzai, Dumetocrinus antarcticus and Ophiura carinifera from the Weddell Sea at $1500 \mathrm{~m}$ depth. Data are means \pm SD

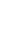



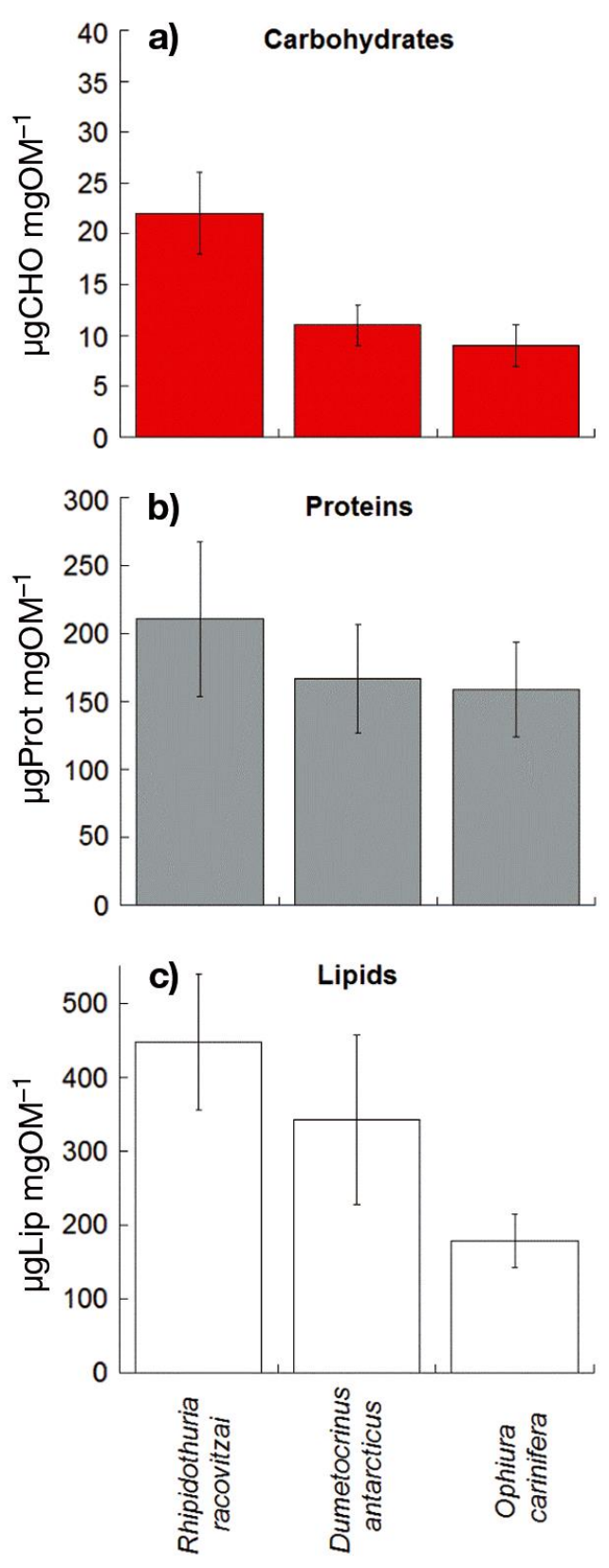

Fig. 3. Biochemical analyses. (a) Carbohydrate (CHO), (b) protein (Prot), and (c) lipid (Lip) content compared to organic matter $(\mu \mathrm{g}$ $\mathrm{mgOM}^{-1}$ ) in the 3 species of echinoderms Rhipidothuria racovitzai, Dumetocrinus antarcticus and Ophiura carinifera from the Weddell Sea at $1500 \mathrm{~m}$ depth. Data are means $\pm \mathrm{SD}$

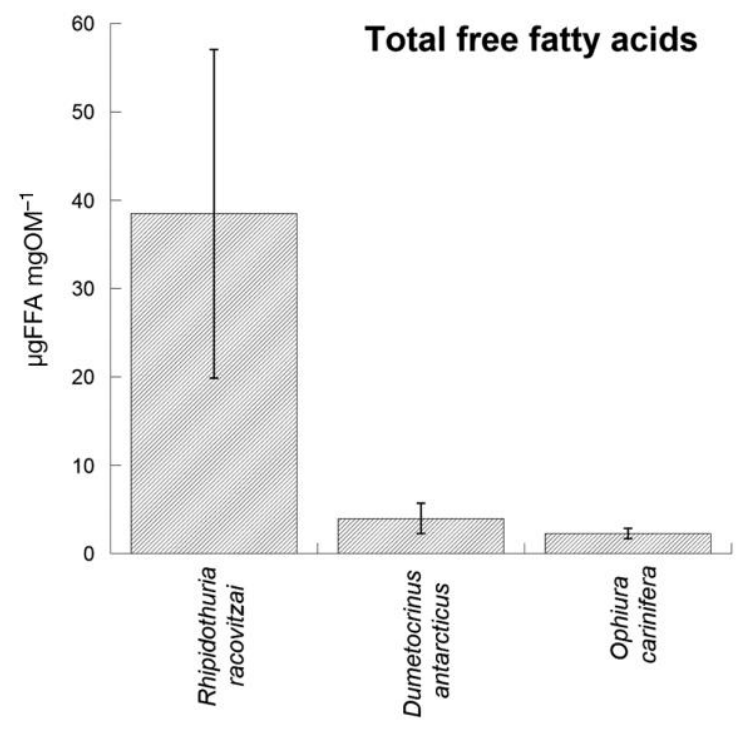

Fig. 4. Total concentration of free fatty acid content compared to organic matter $(\mu \mathrm{gFFA}$ $\mathrm{mgOM}^{-1}$ ) of 3 species of echinoderms Rhipidothuria racovitzai, Dumetocrinus antarcticus and Ophiura carinifera from the Weddell Sea at $1500 \mathrm{~m}$ depth. Data are means $\pm \mathrm{SD}$

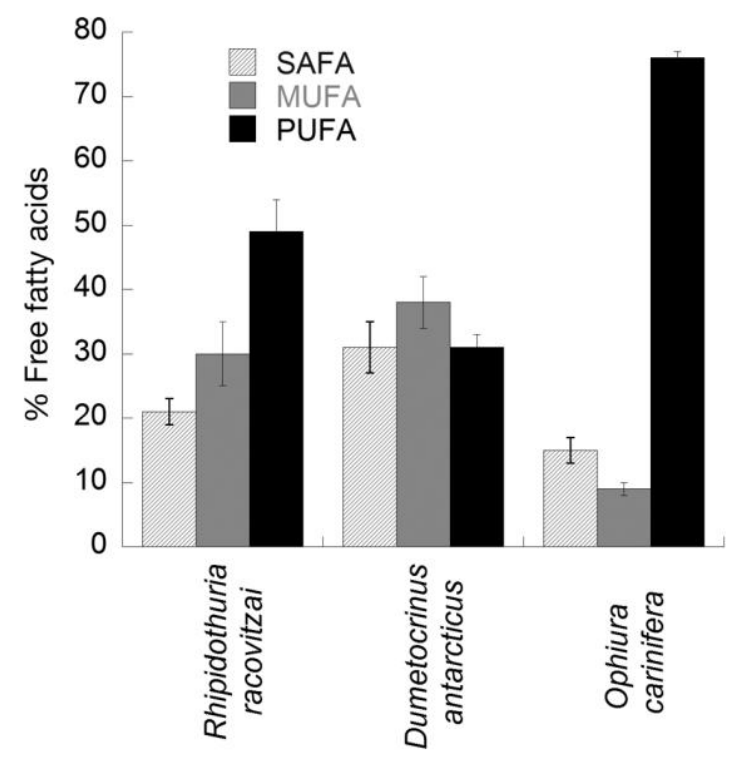

Fig. 5. Proportions (\%) of the different groups of free fatty acids (SAFA: saturated; MUFA: mono-unsaturated; PUFA: polyunsaturated) of 3 species of echinoderms Rhipidothuria racovitzai, Dumetocrinus antarcticus and Ophiura carinifera from the Weddell Sea at $1500 \mathrm{~m}$ depth. Data are means \pm SD 
682 2

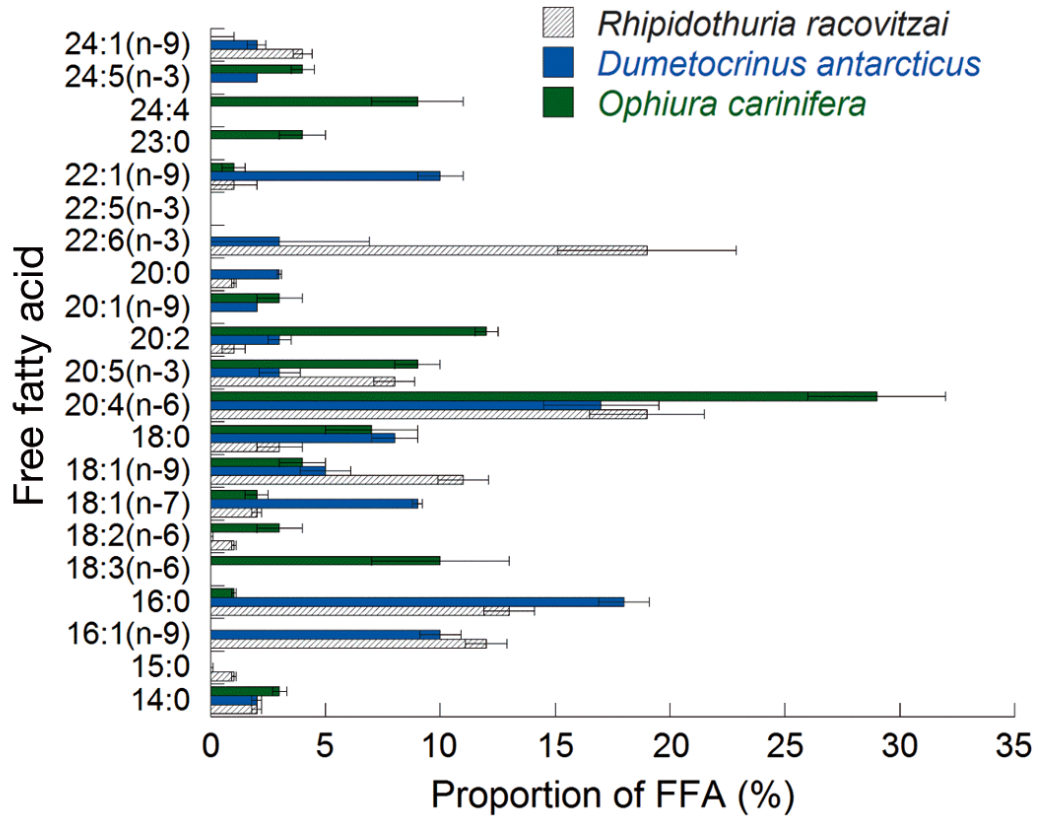

Fig. 6. Free fatty acid (FAA) composition (as a\% of the total FFAs) of 3 species of echinoderms Rhipidothuria racovitzai, Dumetocrinus antarcticus and Ophiura carinifera from the Weddell Sea at $1500 \mathrm{~m}$ depth. Data are means \pm SD

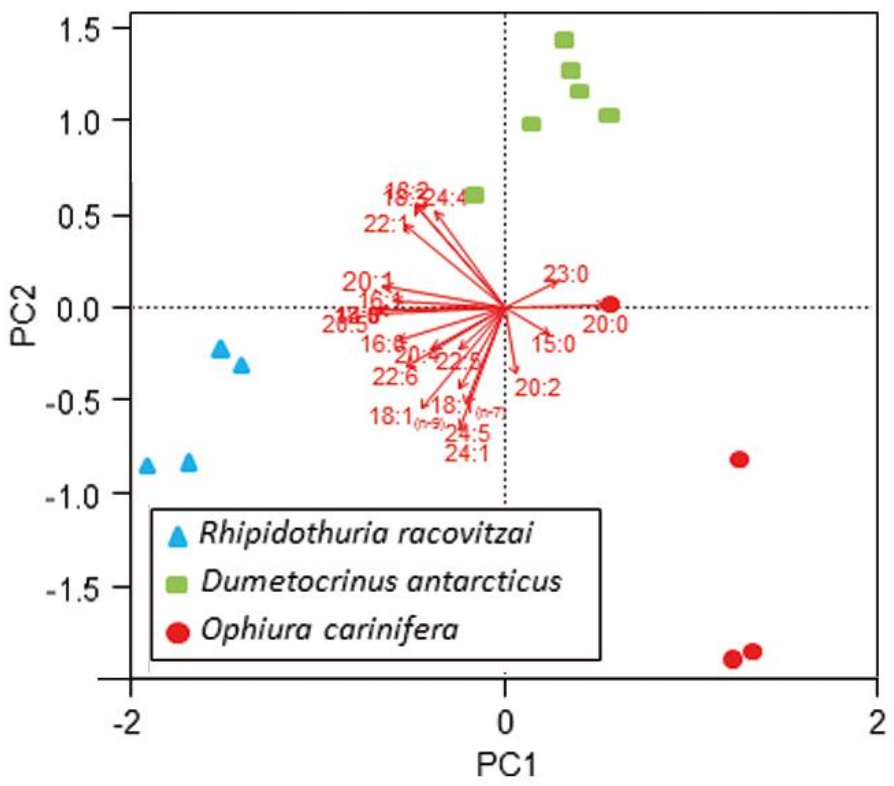

Fig. 7. Principal component analysis (PCA) of the representative fatty acids in the 3 species of echinoderms Rhipidothuria racovitzai, Dumetocrinus antarcticus and Ophiura carinifera from the Weddell Sea at $1500 \mathrm{~m}$ depth 